\title{
ПОИСК 2-ОКСИНДОЛЬНЫХ ИНГИБИТОРОВ GSК3В С АНТИДИАБЕТИЧЕСКИМ ПОТЕНЦИАЛОМ
}

\author{
В.Г. Клочков ${ }^{1}$, Е.Н. Безсонова ${ }^{2}$, Д.Д. Мелехина², М. Дубар \\ ${ }^{1}$ Кафедра фармакологии и биоинформатики, ФГБОУ ВО ВолгГМУ Минздрава России, \\ 400131, Россия, Волгоград, пл. Павших борцов, 1. \\ ${ }^{2}$ Кафедра медицинской химии и тонкого органического синтеза \\ химического факультета ФГБОУ ВО МГУ, \\ 119991, Москва, Ленинские горы, дом 1, строение 3, ГСП-1.
}

DOI: 10.19163/MedChemRussia2021-2021-333

E-mail:klochkovvladlen@gmail.com

Изучено влияние 16 новых производных 2-оксиндола на активность киназы гликогенсинтазы типа 3 бета (GSK3B) человека [1]. Выявлено 1 соединение (K-167), оказывающее большее ингибирующее GSK3B действие в конечной концентрации 10 мкM, чем вещество сравнения SB-21673; 4 соединения проявили активность выше 50\% (K-165, K-167, K-248, OІP-NO2-2) [2]. Показано, что для 3-арилиден-2оксиндольных скаффолдов при наличии гетероатома в орто- или гидроксильной группы в пара-положении арильного заместителя возрастает ингибирующая GSK3B активность соединений. Соединение K-167 ( $\mathrm{R}^{1}$ - (пиридин-2-ил)метилиден; $\left.\mathrm{R}^{2}-\mathrm{H}\right)$ $\left(\mathrm{IC}_{50} 4,2\right.$ нM) в два раза превосходит по активности вещество сравнения $\left(\mathrm{IC}_{50} 8,4 \mathrm{HM}\right)$.

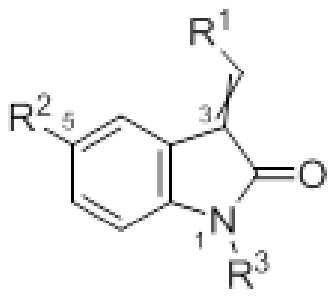

Puс. 1. Структурная формула изученных соединений.

Показана его высокая антидиабетическая активность при однократном и курсовом введении животным с моделированным сахарным диабетом 2 типа. Выявлено наличие противовоспалительной, антиагрегатной, антитромботической и антиоксидантной активностей, что является характерным для данного класса соединений [3].

Синтетическая часть работы выполнена при поддержке гранта РФФИ № 20-03-00915a.

\section{Литература}

1. Лозинская Н.А., Зарянова Е.В., Бабков Д.А., Клочков В.Г., Спасов А.А., Ефремов А.М., Безсонова Е.М. Ц.М.Д. Патент №2734495 Способ лечения сахарного диабета. 2020.

2. Lozinskaya N.A. и др. Synthesis and biological evaluation of 3-substituted 2-oxindole derivatives as new glycogen synthase kinase 3 $\beta$ inhibitors // Bioorganic Med. Chem. 2019.

3. Liu S.K. и др. An updated research of glycogen synthase kinase-3 $\beta$ inhibitors: a review // Monatshefte fur Chemie. Springer Vienna, 2021. T. 152, № 1. C. 19-33. 